\title{
The influence of adding tomato extract and acetylsalicylic acid to hypotensive therapy on the daily blood pressure profiles of patients with arterial hypertension and high cardiovascular risk
}

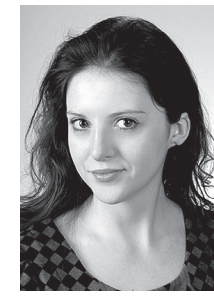

Angelika N. Osińska ${ }^{1}$, Beata Begier-Krasińska1, Piotr Rzymski ${ }^{2}$, Aleksandra Krasińska ${ }^{3}$, Andrzej Tykarski ${ }^{1}$, Zbigniew Krasiński ${ }^{4}$

${ }^{1}$ Department of Hypertensiology, Angiology, and Internal Diseases, Poznan University of Medical Sciences, Poland

2Department of Environmental Medicine, Poznan University of Medical Sciences, Poland

${ }^{3}$ student at Medical Faculty I, Poznan University of Medical Sciences, Poland

${ }^{4}$ Department of General and Vascular Surgery, Poznan University of Medical Sciences, Poland

Kardiochirurgia i Torakochirurgia Polska 2017; 14 (4): 245-252

\begin{abstract}
Introduction: Arterial hypertension (HT) is one of the most common diseases around the world and constitutes a significant medical, social, and economic problem. Lifestyle changes, including adequate fruit and vegetable consumption, play an important role in controlling blood pressure (BP) and other cardiovascular risk factors.

Aim: To compare the influence of adding acetylsalicylic acid (ASA) or standardized tomato extract (STE) to standard hypotensive therapy on the values of arterial pressure and the daily blood pressure profiles of patients with hypertension and high cardiovascular risk.

Material and methods: The study included 65 patients with arterial hypertension and high cardiovascular risk. High-risk patients with primary hypertension were randomly allocated in a blinded fashion to one of two groups (ASA or STE). In each case, two visits were made: the first - before the treatment, and the second - after 4 weeks of treatment. During each visit, the patients underwent a clinical measurement of arterial pressure and an ambulatory blood pressure measurement (ABPM). Blood platelet aggregation was assessed using the VerifyNow analyzer.

Results: After 4 weeks of treatment, the blood pressure values during the day $(p<0.001)$, during the night $(p<0.05)$, and in 24-h BP profiles $(p<0.01)$ obtained with ABPM were significantly lower in the STE group in comparison to the ASA group. The addition of STE to standard hypotensive treatment resulted in a favorable increase in the nocturnal fall of diastolic blood pressure (DBP) (by 6.5\%) and mean arterial pressure (MAP) (by 3.3\%).

Conclusions: The use of STE is significant in HT patients with high total cardiovascular risk; it is associated with better BP control and improvements in the daily BP profile.
\end{abstract}

\section{Streszczenie}

Wstęp: Nadciśnienie tętnicze to jedna z najczęściej występujących chorób na świecie, która stanowi poważny problem medyczny, społeczny i ekonomiczny. Modyfikacja stylu życia, w tym odpowiednia podaż warzyw i owoców w diecie, odgrywa istotną rolę w kontroli ciśnienia tętniczego oraz pozostałych czynników ryzyka sercowo-naczyniowego.

Cel: Porównanie wpływu dodania do standardowej terapii hipotensyjnej preparatów kwasu acetylosalicylowego (ASA) bądź standaryzowanego ekstraktu z pomidorów (STE) na wartości ciśnienia tętniczego oraz profil dobowy ciśnienia u pacjentów z nadciśnieniem obciążonych wysokim ryzykiem sercowo-naczyniowym.

Materiat i metody: Do badania włączono 65 pacjentów z nadciśnieniem tętniczym oraz wysokim ryzykiem sercowo-naczyniowym. Pacjenci z pierwotnym nadciśnieniem i wysokim ryzykiem zostali w sposób zaślepiony, losowo przydzielni do jednej z dwóch grup (ASA lub STE). W każdym przypadku odbyły się dwie wizyty: pierwsza przed leczeniem, a druga po 4 tygodniach leczenia. Podczas każdej wizyty wykonano kliniczne oznaczenie wartości ciśnienia tętniczego, prowadzono też całodobowe monitorowanie ciśnienia tętniczego (ABPM). Agregację płytek krwi oznaczano przy użyciu analizatora VerifyNow. Wyniki: Po 4 tygodniach terapii w grupie STE w porównaniu z grupą ASA wykazano istotne statystycznie zmniejszenie wartości ciśnienia w ciągu dnia $(p<0,001)$, w nocy $(p<0,05)$ i w całodobowym profilu ciśnienia $(p<0,01)$ mierzonych w ABPM. Dodanie STE do standardowej terapii hipotensyjnej spowodowało korzystną tendencję wzrostową spadku nocnego w zakresie rozkurczowego ciśnienia krwi (DBP) o 6,5\% i w zakresie średniego ciśnienia tętniczego (MAP) o 3,3\%.

Wnioski: Zastosowanie STE ma znaczenie u chorych z nadciśnieniem i wysokim całkowitym ryzykiem sercowo-naczynio-

Address for correspondence: Angelika N. Osińska MD, Department of Hypertensiology, Angiology, and Internal Diseases, Poznan University of Medical Sciences, 1/2 Długa St, 61-848 Poznań, Poland, phone: +48 6185490 90, fax: +48 6185490 86, e-mail: angelika.miazga@gmail.com Received: 19.10.2017, accepted: 22.11.2017. 
Key words: arterial hypertension, standardized tomato extract, acetylsalicylic acid, non-dippers, nocturnal blood pressure fall.

\section{Introduction}

Arterial hypertension is one of the most common diseases around the world, constituting a significant medical, social, and economic problem. World Health Organization (WHO) lists this condition as one of the most important global risk factors for death. It is estimated to be responsible for $13 \%$ of all deaths. A linear correlation has been found between the values of systolic arterial pressure (SBP) and the incidence and mortality of cardiovascular diseases (myocardial infarction, stroke, heart failure, peripheral artery disease) and renal diseases. Proper modification of lifestyle plays the key role in hypertension $(\mathrm{HT})$ prevention and is an indispensable component of therapy.

Population studies demonstrated that the percentage of inhabitants suffering from arterial hypertension is lower in high-income countries (28.5\%) and higher in low- and middle-income countries (31.5\%) [1]. It has also been confirmed that changes in lifestyle can have a hypotensive effect comparable to that associated with the use of pharmacological monotherapy [2]. Lifestyle changes of proven hypotensive effectiveness include: low-fat diets rich in vegetables and fruit, limiting the use of salt and alcohol, body mass reduction, regular physical exercise, and cessation of smoking. Appropriate lifestyle changes can also improve the control of the remaining cardiovascular risk factors [2]. Patients with arterial hypertension are recommended to consume 300-400 g of fruit and vegetables [2].

Current literature on cardiovascular prevention raises the importance of functional foods. Apart from nutritional value, their advantages include the reduction of low-density lipoprotein (LDL) cholesterol concentration, blood pressure control, and maintenance of normal blood coagulability [3]. One example of a functional food is tomatoes and tomatobased products. Tomatoes are a rich source of natural antioxidants, such as polyphenols, vitamins $\mathrm{E}$ and $\mathrm{C}$, and carotenes, which inhibit the process of atherosclerotic plaque formation. In 2009, standardized tomato extracts were approved by the European Food Safety Authority (EFSA) as dietary agents for maintaining proper blood platelet aggregation [4]. Mediterranean diet, rich in fruit and vegetables (tomatoes in particular), exhibits significant cardioprotective properties, as confirmed by scientific studies [5]. The anti-atherosclerotic, antiplatelet, and hypotensive properties of tomato extracts stem from bioactive compounds including flavonoids, phenolic acids, and nucleosides [6]. These compounds have been shown to inhibit renin activity and reduce the expression of angiotensin II-converting enzyme [7, 8]. Polyphenols can also influence the formation wym, wiąże się z lepszą kontrolą wartości ciśnienia i poprawą dobowego profilu ciśnienia.

Słowa kluczowe: nadciśnienie tętnicze, standaryzowany ekstrakt z pomidorów, kwas acetylosalicylowy, non-dippers, spadek nocny ciśnienia tętniczego.

of endothelial nitric oxide (NO), leading to vasodilation and blood pressure reduction [9].

The influence of hypertension on cardiovascular risk also depends on the daily fluctuations of blood pressure. Numerous studies have demonstrated greater risk of developing subclinical organ injuries in the group of patients known as non-dippers, in whom the nocturnal blood pressure fall (NBPF) does not exceed 10-20\% during waking hours [10]. This group significantly more often suffers from left ventricular hypertrophy, microalbuminuria, intimal and medial thickening of the carotid artery, and neurological complications. The degree of NBPF has prognostic value as well. The association between the lack of NBPF and cardiovascular risk has been confirmed [11].

The best explored action mechanism of acetylsalicylic acid (ASA) is its antiplatelet effect, but the agent also has other properties. Several studies reported a beneficial hypotensive effect after the addition of small doses of aspirin to hypotensive agents. Acetylsalicylic acid can contribute to the reduction of both systolic and diastolic blood pressure (SBP and DBP) by improving endothelial function [12]. There are few reports on the hypotensive action of standardized tomato extract (STE) and its impact on NBPF [13].

\section{Aim}

The aim of this study was to determine whether the addition of antiplatelet preparations (STE and ASA) to standard hypotensive therapy influences blood pressure and daily BP profiles in hypertensive patients with high cardiovascular risk.

\section{Material and methods Study design}

The study involved 82 high-risk hypertensive patients (44 men and 38 women, aged 28-74 years), and it was conducted between July 2015 and February 2017 in the Department of Hypertension at the Poznan University of Medical Sciences. Seventeen patients withdrew their consent during the study. The study was approved by the local Bioethical Committee of the Poznan University of Medical Sciences (permission no. 377/15) and was, therefore, performed in accordance with the ethical standards laid down in the 1964 Declaration of Helsinki and its later amendments. All patients undersigned written consent forms. The study was listed in the Registration and Results System and obtained the following ClinicalTrials.gov ID: NCT03206944. Patients with primary arterial hypertension and high or very high 
total cardiovascular risk were randomized in a blinded fashion (using sealed envelopes) to one of two groups [2]. Group 1 (ASA) included 33 patients who received ASA at a dose of $75 \mathrm{mg}$ in the morning in addition to standard hypotensive therapy. Group 2 (STE) included 32 patients receiving STE (ZAAX, Sequia, Poland) at a dose of $213 \mathrm{mg}$ orally in the morning. The patients received two visits: one to determine baseline values and one after four weeks of treatment, according to the scheme presented in Figure 1. There were no changes in the concomitant treatment (lipid-lowering, antihypertensive, or antidiabetic), and no nonsteroidal anti-inflammatory drugs (NSAIDs) were used during the study. There were no intergroup differences in the amount or type of antihypertensive drugs.

The exclusion criteria for the study were as follows: secondary hypertension, white coat hypertension, coronary artery disease, myocardial infarction, revascularization, stroke, transient ischemic attack (TIA), peripheral arterial disease (PAD), congestive heart failure, chronic kidney disease (glomerular filtration ratio (GFR) $<30 \mathrm{ml} /$ min), addiction to alcohol or psychotropic substances, active cancer, congenital or acquired hemostatic disorder, and use of ASA, STE, or other antiplatelet agents within 14 days prior to the study. Additional exclusion criteria for group 2 included hypersensitivity to ASA and active gastric or duodenal ulcers.

\section{Blood pressure measurements}

In all the patients, during each visit, clinical blood pressure (BP) measurements were performed three times at rest, in a supine position, in standard conditions, using an upper-arm blood pressure monitor (Omron 705IT). Ambulatory, 24-hour blood pressure measurements (ABPM) were carried out using an A\&D 24-hour ambulatory peripheral blood pressure monitor. The frequency of measurements was every 15 min between 7:00 and 22:00, and every 30 min between 22:00 and 7:00. Subsequently, mean arterial pressure (MAP) was calculated from the formula MAP $=\mathrm{DBP}+1 / 3(\mathrm{SBP}-\mathrm{DBP})[\mathrm{mm} \mathrm{Hg}]$, and pulse pressure (PP) was calculated from the formula $P P=S B P$ - DBP [mm Hg]. Mean diurnal and nocturnal values of SBP and DBP were analyzed. The percentage drop in blood pressure was calculated using the following equation: \% drop in SBP $=[(\mathrm{SBP}$ day - SBP night)/SBP day] $\times 100 \%$.

Similarly, the percentage drop in diastolic and mean blood pressure (night blood pressure fall - NBPF) was calculated. Patients with normal NBPF (10-20\%) are referred to as "dippers". Patients with NBPF $<10 \%$ were classified as "non-dippers", and patients with NBPF exceeding $20 \%$ were classified as "extreme dippers" [14].

\section{VerifyNow ${ }^{\circledR}$ test procedure}

Whole blood samples were collected from a peripheral vein at $1-4 \mathrm{~h}$ after the ingestion of a morning dose of ASA or STE, using a 21-gauge needle in a partial fill $3.2 \%$ citrate vacuum collection tube. In the study, two types of VerifyNow test kits were used: the VerifyNow Aspirin test and the VerifyNow P2Y12 test. Platelet function was mea-

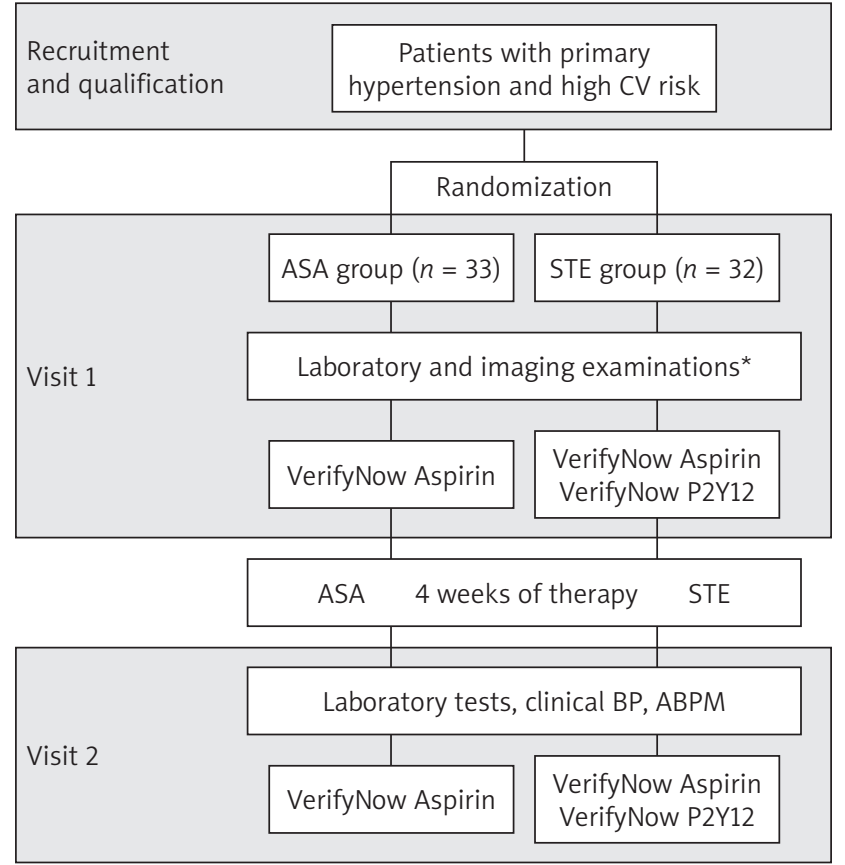

Fig. 1. Study design scheme

*In each group: laboratory tests, abdominal ultrasound, abdominal CT, Doppler ultrasound of renal arteries, clinical BP ( $3 \times / 24$ h), ABPM, ECG, echocardiography, weight and body mass index assessment.

sured at baseline and after 4 weeks of treatment. In group 1 (ASA), the VerifyNow Aspirin test was assayed. In group 2, due to the possible pleiotropic action of STE, the VerifyNow Aspirin and P2Y12 VerifyNow tests were performed. The aspirin test results are reported as aspirin reaction units (ARU), which are calculated as a function of the rate of aggregation. The ARU values lower than than 550 indicate an effective result of ASA, while values > $550 \mathrm{ARU}$ indicate no effect of the drug. The VerifyNow P2Y12 test measures platelet function based on the ability of activated platelets to bind fibrinogen; it provides information on platelet aggregation in $\mathrm{P} 2 \mathrm{Y} 12$ reactivity units (PRU). It is considered that optimal antiplatelet activity falls in the range of 95-208 PRU.

\section{Statistical analysis}

Statistical analyses were performed with Statistica, version 12.5. (StatSoft, USA). Since the tested data had not met the assumption of Gaussian distribution (evaluated with the Shapiro-Wilk method), non-parametric methods were applied. The Wilcoxon signed-rank test was used for evaluation of the differences between the initial and posttreatment values in terms of body weight composition, blood pressure, and platelet aggregation. To evaluate the differences and correlations between the two independent groups, the Mann-Whitney $U$ test and Spearman's rank correlation coefficient (Rs) were used respectively. The data presented in the graphs and tables included median and interquartile ranges. A $p$-value $<0.05$ was considered significant. 


\section{Results}

The detailed demographic data of the studied groups have been presented in Table I. There were no statistically significant differences $(p>0.05)$ between these groups in terms of age or body mass index (BMI) (Tab. I). The baseline blood and lipid profile parameters did not show statistically significant differences between the groups $(p>0.05)$, except for the higher triglyceride (TG) concentration in the STE group ( $p<0.05$; Tab. II). No changes in these parameters were observed in either group after 4 weeks of therapy $(p<0.05$ in all cases). At baseline, the results of ABPM were significantly $(p<0.05)$ higher in the STE group than in the ASA group. After 4 weeks of treatment in the STE group, there was a statistically significant reduction in BP during the day $(p<0.001)$, during the night $(p<0.05)$, and in 24hour BP $(p<0.01)$ values obtained with ABPM (Tab. III). The prevalence of non-dippers, dippers, and extreme dippers before and after the ASA or STE treatment did not differ significantly between the groups $(p<0.05$; Tab. IV). There was an increase in the percentage drop of DBP by $6.5 \%$,

Tab. I. Demographic characteristics of patients treated with ASA or STE at Visit 1 (median and interquartile range)

\begin{tabular}{|c|c|c|}
\hline Parameter & $\begin{array}{l}\text { ASA group } \\
(n=33)\end{array}$ & $\begin{array}{l}\text { STE group } \\
(n=32)\end{array}$ \\
\hline Female/male, $n$ & $19 / 14$ & $8 / 24$ \\
\hline Age [years] & $53(44-63)$ & $54.5(45-72)$ \\
\hline BMI $\left[\mathrm{kg} / \mathrm{m}^{2}\right]$ & $31.1(27.4-36.3)$ & $27.7(25.3-33.4)$ \\
\hline \multicolumn{3}{|l|}{ BMI group: } \\
\hline Normal (18.5-24.9kg/m²) & 5 & 6 \\
\hline Overweight (25.0-29.9 kg/m²) & 10 & 12 \\
\hline Obesity $(>30.0$ kg/m²) & 18 & 14 \\
\hline Smokers & 4 & 4 \\
\hline $\begin{array}{l}\text { Concomitant lipid-lowering } \\
\text { therapy }\end{array}$ & 29 & 28 \\
\hline $\begin{array}{l}\text { Concomitant antidiabetic } \\
\text { therapy (metformin) }\end{array}$ & 2 & 2 \\
\hline $\begin{array}{l}\text { Number of antihypertensive } \\
\text { agents/patient [median] }\end{array}$ & 2.9 & 3.2 \\
\hline Diuretics & 25 & 22 \\
\hline Aldosterone antagonists & 8 & 6 \\
\hline $\begin{array}{l}\text { Angiotensin-converting } \\
\text { enzyme inhibitors }\end{array}$ & 24 & 23 \\
\hline $\begin{array}{l}\text { Angiotensin II receptor } \\
\text { antagonists }\end{array}$ & 15 & 13 \\
\hline Calcium antagonists & 11 & 10 \\
\hline$\beta$-blockers & 17 & 16 \\
\hline$\alpha$-blockers & 1 & 2 \\
\hline ARU & $574(541-628)$ & $582(533-604)$ \\
\hline PRU & Not done & 228 (149-309) \\
\hline
\end{tabular}

BMI - body mass index, ARU - aspirin reaction units, PRU - P2Y12 reaction units but statistical significance was not obtained. The percentage drop in systolic BP decreased significantly, and the direction of these changes was unfavorable from the dipper to non-dipper group $(p<0.05$; Fig. 2). After the treatment, the percentage drop in mean blood pressure fall (NBPF) increased by $1.25 \%$ in the ASA group (insignificantly $p>0.05$ ) and by $3.3 \%$ in the STE group ( $p<0.05$; Fig. 3). Side effects, such as bleeding, were not recorded in either of the groups. In the presented analysis, ASA resistance was confirmed in $24.2 \%$ of the patients (8 from 33 patients).

\section{Discussion}

Our aim was to assess the influence of two different antiplatelet preparations on blood pressure values and daily pressure profiles. The STE (dosed at $213 \mathrm{mg} /$ day) was added to standard hypotensive therapy; after 4 weeks, ABPM demonstrated beneficial reductions of systolic, diastolic, and mean pressure. The study group comprised patients with high and very high cardiovascular risk according to the ECS/ ESH 2013 classification [2]. A similar effect on BP in comparison to placebo was observed when hypertensive patients receiving hypotensive treatment were administered tomato extract for 6 weeks. It was demonstrated that adding STE to hypotensive therapy causes a clinically significant reduction in SBP by over $10 \mathrm{~mm} \mathrm{Hg}$ and DBP by over $5 \mathrm{~mm} \mathrm{Hg}$. A correlation was also noted between the values of of systolic pressure and the level of lycopene. The authors suggested that the hypotensive effect is associated with synergistic antioxidant action [15]. A different study presented another possible mechanism of hypotensive STE action, namely the serum increase of nitric oxide - a natural vasodilator with strong antioxidant properties. Polyphenols

Tab. II. Blood test parameters (median and interquartile range) for the ASA and STE groups at baseline

\begin{tabular}{lcc} 
Parameter & ASA group & STE group \\
GLC $[\mathrm{mmol} / \mathrm{l}]$ & $5.6(5.1-6.3)$ & $5.8(5.2-6.2)$ \\
\hline $\mathrm{TG}[\mathrm{mmol} / \mathrm{l}]^{*}$ & $1.0(0.8-1.4)$ & $1.6(1.1-2.2)$ \\
\hline $\mathrm{LDL}[\mathrm{mmol} / \mathrm{l}]$ & $2.8(2.3-3.4)$ & $2.5(2.1-3.3)$ \\
\hline $\mathrm{TC}[\mathrm{mmol} / \mathrm{l}]$ & $4.9(4.3-5.2)$ & $5.1(4.0-5.6)$ \\
\hline $\mathrm{HDL}[\mathrm{mmol} / \mathrm{l}]$ & $1.3(1.1-1.7)$ & $1.2(1.0-1.5)$ \\
\hline $\mathrm{Na}[\mathrm{mmol} / \mathrm{l}]$ & $141(139-143)$ & $142(140-143)$ \\
\hline $\mathrm{K}[\mathrm{mmol} / \mathrm{l}]$ & $4.3(4.1-4.6)$ & $4.2(3.9-4.6)$ \\
\hline Serum creatinine $[\mu \mathrm{mol} / \mathrm{l}]$ & $79.0(70.9-87.9)$ & $92.1(69.9-111.5)$ \\
\hline Uric acid $[\mu \mathrm{mol} / \mathrm{l}]$ & $271.0(196.0-312.0)$ & $313.0(251.0-348.6)$ \\
\hline HGB $[\mathrm{mmol} / \mathrm{l}]$ & $9.0(8.7-9.4)$ & $9.3(8.8-10.0)$ \\
\hline HCT $[\mathrm{l} / \mathrm{l}]$ & $0.4(0.4)$ & $0.4(0.4-0.5)$ \\
\hline PLT $\left[10^{-9} / \mathrm{l}\right]$ & $241.0(189.0-276.0)$ & $223.0(204.0-257.5)$ \\
\hline Statsicly sgnfican &
\end{tabular}

*Statistically significant difference between the ASA group and the STE group ( $p<0.05$, Mann-Whitney U test). GLC - glucose, TG - triglyceride, LDL - LDL cholesterol, TC - total cholesterol, HDL - HDL cholesterol, HGB - hemoglobin, HCT - hematocrit, PLT - platelets 
Tab. III. Results of ambulatory blood pressure monitoring for ASA and STE before (visit 1) and after treatment (visit 2) with statistical comparisons performed using the Wilcoxon signed-rank test (WLCXN)

\begin{tabular}{|c|c|c|c|c|c|}
\hline BP & Parameter & Group & Visit 1 & Visit 2 & $\begin{array}{l}\text { WLCXN } \\
P \text {-value }\end{array}$ \\
\hline \multirow[t]{8}{*}{ BP day } & SBPd & ASA & $130.0(123.0-139.0)$ & 130.0 (123.0-139.0) & NS \\
\hline & & $\mathrm{STE}^{*}$ & $141.5(125.5-149.0)$ & 130.0 (122.0-137.0) & $<0.001$ \\
\hline & DBPd & ASA & $77.0(72.0-84.0)$ & $76.0(70.0-83.0)$ & NS \\
\hline & & $\mathrm{STE}^{*}$ & 84.5 (76.0-92.5) & $80.0(75.0-83.5)$ & $<0.01$ \\
\hline & MAPd & ASA & $94.5(89.0-103.0)$ & $93.0(88.0-100.5)$ & NS \\
\hline & & $\mathrm{STE}^{*}$ & $103.0(93.0-112.0)$ & $98.0(90.0-101.5)$ & $<0.001$ \\
\hline & HRd & ASA & $72.0(66.0-80.0)$ & $71.0(63.0-79.0)$ & NS \\
\hline & & STE & $74.0(69.0-80.0)$ & $72.0(68.0-76.0)$ & NS \\
\hline \multirow[t]{8}{*}{ BP night } & SBPn & ASA & $113.0(108.0-123.0)$ & $116.0(107.0-125.0)$ & NS \\
\hline & & $\mathrm{STE}^{*}$ & $120.0(109.5-126.5)$ & $110.0(106.0-122.5)$ & $<0.05$ \\
\hline & DBPn & ASA & $66.0(63.0-72.0)$ & $67.0(60.0-70.0)$ & NS \\
\hline & & $\mathrm{STE}^{*}$ & $69.0(64.0-78.0)$ & $66.0(64.5-71.0)$ & $<0.05$ \\
\hline & MAPn & ASA & $80.0(78.0-90.0)$ & $81.0(76.0-90.0)$ & NS \\
\hline & & $\mathrm{STE}^{*}$ & $85.0(80.0-95.0)$ & $80.5(76.5-88.5)$ & $<0.05$ \\
\hline & HRn & ASA & $61.0(57.0-67.0)$ & $59.0(57.0-63.0)$ & NS \\
\hline & & $\mathrm{STE}^{*}$ & $62.0(54.0-66.0)$ & $64.0(54.5-65.5)$ & $<0.05$ \\
\hline \multirow[t]{8}{*}{$24 \mathrm{~h} \mathrm{BP}$} & SBP24 & ASA & $125.0(120.0-137.0)$ & $126.0(120.0-137.0)$ & NS \\
\hline & & $\mathrm{STE}^{*}$ & 137.5 (122.0-143.0) & $127.0(118.0-132.0)$ & $<0.001$ \\
\hline & DBP24 & ASA & $74.0(70.0-81.0)$ & $73.0(70.0-80.0)$ & NS \\
\hline & & $\mathrm{STE}^{*}$ & $80.5(74.0-88.0)$ & $78.0(73.5-80.5)$ & $<0.01$ \\
\hline & MAP24 & ASA & $91.0(87.0-99.0)$ & $92.0(86.0-96.0)$ & NS \\
\hline & & $\mathrm{STE}^{*}$ & $99.0(91.0-107.0)$ & $94.0(87.5-98.0)$ & $<0.01$ \\
\hline & HR24 & ASA & $70.0(64.0-77.0)$ & $69.0(61.0-77.0)$ & NS \\
\hline & & STE & $71.0(66.0-76.0)$ & 70.5 (66.0-74.0) & NS \\
\hline
\end{tabular}

*Statistically significant difference between the ASA group and the STE group $(p<0.05$, Mann-Whitney U test). BP - blood pressure, SBPd - ambulatory daytime systolic blood pressure, DBPd - ambulatory daytime diastolic blood pressure, MAPd - ambulatory daytime mean blood pressure, HRd - heart rate in the day, SBPn - ambulatory nighttime systolic blood pressure, DBPn - ambulatory nighttime diastolic blood pressure, MAPn - ambulatory nighttime mean blood pressure, HRn heart rate in the night, SBP24 - 24-h systolic blood pressure, DBP24 - 24-h diastolic blood pressure, HR24 - 24-h heart rate, MAP24 - 24-h ambulatory mean blood pressure.

Tab. IV. Frequency of non-dippers, dippers, and extreme dippers before and after the ASA or STE treatment

\begin{tabular}{lcccc} 
& \multicolumn{2}{c}{ ASA $(n=33)$} & \multicolumn{2}{c}{ STE $(n=32)$} \\
\cline { 2 - 5 } & Visit 1 & Visit 2 & Visit 1 & Visit 2 \\
\cline { 2 - 5 } Non-dippers & $12(36.3)$ & $11(33.3)$ & $n(\%)$ & $7(21.9)$ \\
\hline Dippers & $15(45.5)$ & $15(45.5)$ & $16(50.0)$ & $17(53.1)$ \\
\hline Extreme dippers & $6(18.2)$ & $7(21.2)$ & $7(21.9)$ & $8(25.0)$
\end{tabular}

Non dippers - nocturnal blood pressure fall (NBPF) < 10\%, dippers - nocturnal blood pressure fall (NBPF) 10-20\%, extreme dippers - nocturnal blood pressure fall $(\mathrm{NBPF})>20 \%$. 


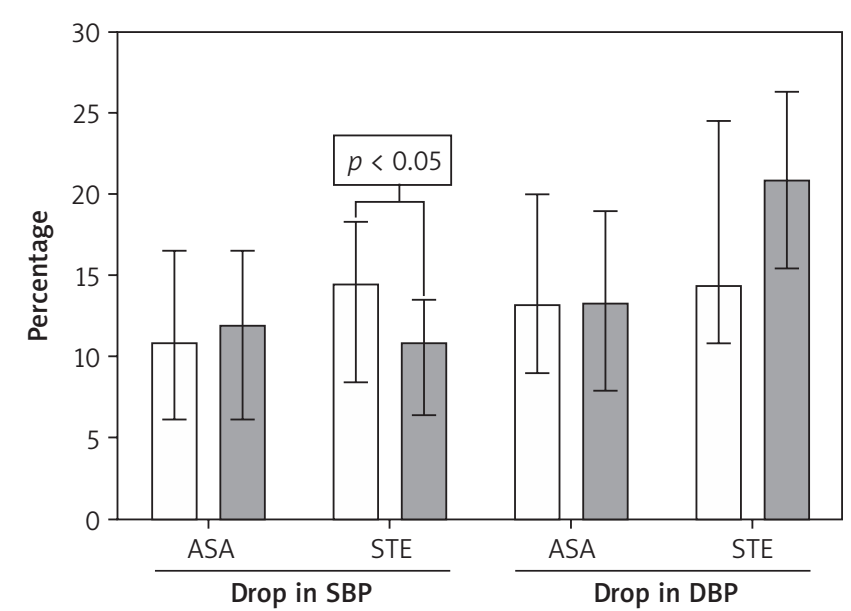

Fig. 2. The results for ABPM parameters: \% drop in systolic and diastolic blood pressure for the STE and ASA groups at baseline (white bars - visit 1) and after 4 weeks of treatment (grey bars visit 2). Reported $p$-value for the Wilcoxon signed-rank test

Drop in SBP - nocturnal systolic blood pressure fall, drop in DBP - nocturnal diastolic blood pressure fall

are considered to have a significant influence on the availability of L-arginine, thus increasing NO concentration [16]. Engelhard et al. proved that short-term treatment with antioxidant-rich tomato extract can reduce blood pressure in patients with grade- 1 hypertension. In their study, patients who did not receive hypotensive agents were administered $250 \mathrm{mg}$ of STE for 2 months, achieving reductions in SBP by $10 \mathrm{~mm} \mathrm{Hg}$ and DBP by $4 \mathrm{~mm} \mathrm{Hg}$ in comparison with placebo [17]. These results are very similar to those obtained in the present study. Other suggested mechanisms of the hypotensive action of STE consist in the reduction of chymase activity and the inhibition and reduction of angiotensin converting enzyme (ACE) and renin expression [8]. It has been demonstrated that tomato extract is a natural source of angiotensin II-converting enzyme inhibitors (comparable with synthetic ACEIs) which reduces arterial pressure [7].

In contrast to STE, the present study failed to confirm a hypotensive effect of ASA. No arterial pressure reduction was observed after 4 weeks of ASA treatment. Similar results were published by Avanzini et al.; after administering small doses of ASA, the researchers noted no reductions in SBP or DBP in patients treated for arterial hypertension [18]. Acetylsalicylic acid in small doses does not influence blood pressure values, nor does it reduce the efficacy of hypotensive medication [19]. This may suggest that the influence of ASA on blood pressure depends on the dosage, which, considering the dose of $75 \mathrm{mg}$ used in our study, might explain the lack of the agent's influence on arterial blood pressure. The hypotensive action of aspirin continues to be a matter of debate. There are reports of ASA's hypotensive influence in patients with arterial hypertension. Magen et al. demonstrated that adding low doses of aspirin to antihypertensive agents and statins in patients with HT and hypercholesterolemia can reduce both SBP and DBP by improving endothelial function [12]. The suggested hypotensive mechanisms include the reduction of vasoconstriction through the inhibition of TXA2 production, and

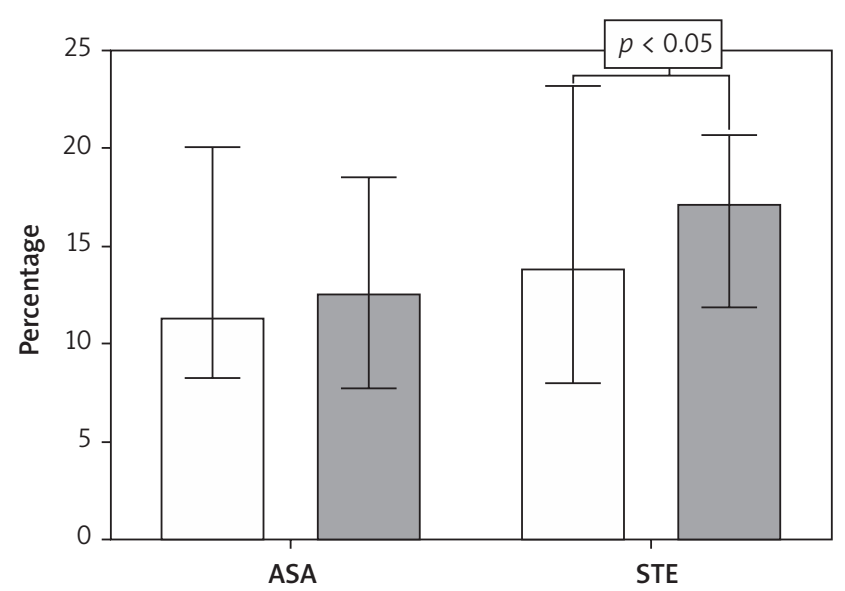

Fig. 3. The results for ABPM parameters: \% drop in mean nocturnal blood pressure fall (NBPF) for the STE and ASA groups at baseline (white bars - visit 1) and after four weeks of treatment (grey bars - visit 2). Reported $p$-value for the Wilcoxon signed-rank test

the increase of vasodilation caused by increased nitric oxide (NO) production due to the stimulation of endothelial nitric oxide synthase (eNOS), reduced in the presence of endothelial dysfunction. Increased NO synthesis protects the endothelium from the detrimental effect of hydrogen peroxide in vitro, inhibits low-density lipoprotein oxidation, induces ferritin synthesis, and hardens the endothelium against oxidative stress injuries; in animal models, it was shown to protect vascular walls from unfavorable effects of angiotensin II action [20-23]. One study demonstrated a beneficial influence of ASA on endothelial function and arterial pressure in 21 patients with primary arterial hypertension. The authors noted that the changes were statistically significant when ASA was administered together with statins. They concluded that the final effect resulted from synergistic pleiotropic action of statins and ASA [12, 24].

The aforementioned results indicate that the studied preparations with antiplatelet properties can reduce blood pressure. Some of the suggested mechanisms of hypotensive action are similar in both ASA and STE. In the present study, the ASA and STE groups had significant baseline differences with regard to pressure values. During the first visit, higher pressure values were observed in the daytime and 24-hour analysis in the STE group. There were no baseline differences between the groups in the dosage or types of hypotensive medication. Importantly, no changes in hypotensive, lipid, or antidiabetic treatment were made during the study. ABPM analysis revealed an additional benefit of STE, i.e., its influence on NBPF. A favorable, though not statistically significant, increase of nocturnal DBP by $6.5 \%$ in comparison to initial values was noted in the STE group (Fig. 2). The increase of the mean NBPF in the STE group $(p<0.05)$ was higher by $3.3 \%$ in comparison to the ASA group, where the drop amounted to only $1.25 \%$, although the difference did not reach statistical significance in ASA group (Fig. 3). 
The undoubted novelty of this publication lies in the fact that it supplements the knowledge of the influence of antiplatelet preparations on BP. The literature features no studies concerning NBPF after the use of STE. The data on this issue with regard to ASA is scant. The reports published so far on the administration of small ASA doses during evening hours demonstrated reductions in nocturnal pressure. In their study from 2005, Hermida et al. analyzed 257 patients with mild HT who received 100 mg of ASA in the evening, demonstrating that the NBPF among dippers was twice as high as that among non-dippers. Significantly, a mild blood pressure increase was noted when ASA was administered in the morning. After analyzing the ABPM results, the researchers found reductions in both nocturnal and office BP measurements [25]. Of significance in this context are the results published previously by this author, which indicated that larger aspiring doses (500 mg) have a vasoconstrictive effect even when administered in the evening, resulting in increased BP [25].

The lack of statistical significance in the presented study could have been associated with with the relatively small number of patients, the administration of the agent only once per day in the morning and the short duration of treatment.

\section{Limitations}

The duration of therapy in our study was relatively short; it is, therefore, unknown whether the favorable hypotensive effect of tomato extract would persist in longer follow-up. The study groups were relatively comparable in size to those analyzed by other authors.

\section{Conclusions}

The use of STE is significant in HT patients with high total cardiovascular risk; it is associated with better BP control and improvements in the daily BP profile.

The presented analysis demonstrated significant hypotensive action of the STE preparation after 4 weeks from its addition to standard hypotensive therapy.

The conducted study may contribute to raising interest in so-called functional foods, especially STE. The search for alternative preparations seems justified as the very broad use of ASA in HT patients (who are always burdened with elevated cardiovascular risk) is being rolled back. The already proven antiplatelet action of STE and its hypotensive action confirmed in this study constitutes a basis for further research.

\section{Disclosure}

Authors report no conflict of interest.

\section{References}

1. Mills KT, Bundy JD, Kelly TN, Reed JE, Kearney PM, Reynolds K, Chen J, He J. Global disparities of hypertension prevalence and control: a systematic analysis of population-based studies from 90 countries. Circulation 2016; 134: 441-450.
2. Mancia G, Fagard R, Narkiewicz K, Redón J, Zanchetti A, Böhm M, Christiaens T, Cifkova R, De Backer G, Dominiczak A, Galderisi M, Grobbee DE, Jaarsma T, Kirchhof P, Kjeldsen SE, Laurent S, Manolis AJ, Nilsson PM, Ruilope LM, Schmieder RE, Sirnes PA, Sleight P, Viigimaa M, Waeber B, Zannad F; Task Force Members. 2013 ESH/ESC Guidelines for the management of arterial hypertension: the Task Force for the management of arterial hypertension of the European Society of Hypertension (ESH) and of the European Society of Cardiology (ESC). J Hypertens 2013; 31: 1281-1357.

3. Krasinska B, Osińska A, Osinski M, Krasinska A, Rzymski P, Tykarski A, Krasiński Z. Standardised tomato extract as an alternative to acetylsalicylic acid in patients with primary hypertension and high cardiovascular risk - a randomised, controlled trial. Arch Med Sci in press doi: 10.5114/ aoms.2017.69864.

4. European Food Safety Authority (EFSA). Water-soluble tomato concentrate (WSTC I and II) and platelet aggregation. EFSA J 2009; 7: n/a-n/a. doi: 10.2903/j.efsa.2009.1101.

5. Godos J, Marventano S, Mistretta A, Galvano F, Grosso G. Dietary sources of polyphenols in the Mediterranean healthy Eating, Aging and Lifestyle (MEAL) study cohort. Int J Food Sci Nutr 2017; 68: 750-756.

6. O'Kennedy N, Raederstorff D, Duttaroy AK. Fruitflow( $\left.{ }^{\circledR}\right)$ : the first European Food Safety Authority-approved natural cardio-protective functional ingredient. Eur J Nutr 2017; 56: 461-482.

7. Biswas D, Uddin MM, Dizdarevic LL, Jørgensen A, Duttaroy AK. Inhibition of angiotensin-converting enzyme by aqueous extract of tomato. Eur J Nutr 2014; 53: 1699-1706.

8. Huang WY, Davidge ST, Wu J. Bioactive natural constituents from food sourc es-potential use in hypertension prevention and treatment. Crit Rev Food Sci Nutr 2013; 53: 615-630.

9. Hügel HM, Jackson N, May B, Zhang AL, Xue CC. Polyphenol protection and treatment of hypertension. Phytomed Int J Phytother Phytopharm 2016; 23 : 220-231.

10. O’Brien E, Asmar R, Beilin L, Imai Y, Mallion JM, Mancia G, Mengden T, Myers M, Padfield P, Palatini P, Parati G, Pickering T, Redon J, Staessen J, Stergiou G, Verdecchia P; European Society of Hypertension Working Group on Blood Pressure Monitoring. European Society of Hypertension recommendations for conventional, ambulatory and home blood pressure measurement. J Hypertens 2003; 21: 821-848.

11. Bendzala M, Kruzliak P, Gaspar L, Soucek M, Mrdovic I, Sabaka P, Dukat A, Gasparova I, Malan L, Takazawa K. Prognostic significance of dipping in older hypertensive patients. Blood Press 2015; 24: 103-110.

12. Magen E, Viskoper JR, Mishal J, Priluk R, London D, Yosefy C. Effects of low-dose aspirin on blood pressure and endothelial function of treated hypertensive hypercholesterolaemic subjects. J Hum Hypertens 2005; 19 : 667-673.

13. Miazga A, Kostka-Jeziorny K, Begier-Krasińska B, Tykarski A. Standarized tomato extract - is an alternative to aspirin in the primary prevention of cardiovascular disease in patients with hypertension. Arter Hypertens 2014; 18: $37-42$.

14. Verdecchia P, Schillaci G, Guerrieri M, Gatteschi C, Benemio G, Boldrini F, Porcellati C. Circadian blood pressure changes and left ventricular hypertrophy in essential hypertension. Circulation 1990; 81: 528-536.

15. Paran E, Novack V, Engelhard YN, Hazan-Halevy I. The effects of natural antioxidants from tomato extract in treated but uncontrolled hypertensive patients. Cardiovasc Drugs Ther 2009; 23: 145-151.

16. Leeuw PW, de Bast A. Tomato extract for hypertension? Cardiovasc Drugs Ther 2009; 23: 107-108.

17. Engelhard YN, Gazer B, Paran E. Natural antioxidants from tomato extract reduce blood pressure in patients with grade- 1 hypertension: a double-blind, placebo-controlled pilot study. Am Heart J 2006; 151: 100.

18. Avanzini F, Palumbo G, Alli C, Roncaglioni MC, Ronchi E, Cristofari M, Capra A, Rossi S, Nosotti L, Costantini C, Pietrofeso R; the Collaborative Group of the Primary Prevention Project (PPP) - Hypertension study. Effects of low-dose aspirin on clinic and ambulatory blood pressure in treated hypertensive patients. Collaborative Group of the Primary Prevention Project (PPP) - Hypertension study. Am J Hypertens 2000; 13: 611-616.

19. Costa AC, Reina-Couto M, Albino-Teixeira A, Sousa T. Aspirin and blood pressure: effects when used alone or in combination with antihypertensive drugs. Rev Port Cardiol 2017; 36: 551-567.

20. Podhaisky HP, Abate A, Polte T, Oberle S, Schröder H. Aspirin protects endothelial cells from oxidative stress: possible synergism with vitamin E. FEBS Lett 1997; 417: 349-351. 
The influence of adding tomato extract and acetylsalicylic acid to hypotensive therapy on the daily blood pressure profiles of patients with arterial hypertension and high cardiovascular risk

21. Oberle S, Polte T, Abate A, Podhaisky HP, Schröder H. Aspirin increases ferritin synthesis in endothelial cells: a novel antioxidant pathway. Circ Res 1998; 82: 1016-1020.

22. Steer KA, Wallace TM, Bolton $\mathrm{CH}$, Hartog M. Aspirin protects low density lipoprotein from oxidative modification. Heart Br Card Soc 1997; 77: 333-337.

23. Shiff SJ, Shivaprasad P, Santini DL. Cyclooxygenase inhibitors: drugs for cancer prevention. Curr Opin Pharmacol 2003; 3: 352-361.
24. Nadar S, Blann AD, Lip GYH. Antihypertensive therapy and endothelial function. Curr Pharm Des 2004; 10: 3607-3614.

25. Hermida RC, Ayala DE, Calvo C, López JE. Aspirin administered at bedtime, but not on awakening, has an effect on ambulatory blood pressure in hypertensive patients. J Am Coll Cardiol 2005; 46: 975-983. 